\title{
Equilibrium Position of Two Particles Moving in a viscous fluid inside a Cylinder \\ 正 篠原 勝 (岐阜高専)
}

Masaru SHINOHARA, Gifu National College of Technology, Shinsei-cho, Motosu-gun, Gifu 501-0495

Keywords: multiphase flow, low Reynolds number, inside a cylinder, two moving particles

\section{1. 緒言}

流体の輸送機構の多くは円管であり、その中に満たされた 流体中を粒子が移動するときに、粒子に㗢く力を調べること は興味梁いことがらである。これまで、多くの研究者がこの 問題に取り組んできたが、現象を支配する Navier-Stokes 方 程式の非線形項を正確に扱うことが困難なので、未解明部分 も多い。

我々はこれまで、円管内を進行する微小球に働く力を理論 および実験的に求めてきた ${ }^{2-4)}$ 。その結果、円管内を軸方向 に進行する単一粒子には中心軸に向かう横方向の力が働く ことを定量的に示し、軸対称 2 粒子は中心軸から半径の約 0.4 倍の位置に向かって横移動することを明らかにした。し かし、ここに述べた半径の約 0.4 倍の位置は、2粒子が軸対 称に制限されている場合であり、中立不安定の可能性もある。 本研究では、管内粘性流体中を任意の位置関係で進行する 2 粒子に㗢く力を調べ、平衡位置の存在可能性について吟味 した。このとき、平行 2 平板間を進行する粒子の横移動を求 めるときに P. Vasseur と R.G.Cox が用いた matched asymptotic expansions method を円筒境界に㹡張して解析し た。球径を基にしたレイノルズ数 Re、及び、管径しに対する 球径 $a$ の比 $\varepsilon$ は十分小さいが、管径を基にしたレイノルズ数 $\mathrm{R}_{\mathrm{L}}$ は必ずしも小さくないとした。

$$
\begin{aligned}
& R_{L}=\frac{v L}{v}=O(1), \\
& \operatorname{Re}=\frac{v a}{v} \ll 1, \\
& \varepsilon=\frac{a}{L}<1 . \\
& \text { ここで、vは動粘性保数、vは流体の速度である。 }
\end{aligned}
$$

\section{2. 基礎方程式}

基䃈方程式は、連続の方程式と定常ナヴィエ・ストークス 方程式である。

$\nabla \cdot v=0$,

$$
\operatorname{Re}(\boldsymbol{v} \cdot \nabla) v=-\nabla p+\Delta v
$$

ここで $p$ は圧力である。円管内壁および球表面で滑り無しの 条件を課し、球から遠く離れた領域で流体は静止していると 考える。

粒子近傍でのみ成り立つ内部展開は $v=v_{0}+R_{\theta} v_{1}+o(R e)$, $p=p_{0}+\operatorname{Re} p_{1}+o(R e)$.
である。これを基礎方程式に代入すると、内部基礎方程 式

$\nabla \cdot v_{0}=0$

$\Delta v_{0}-\nabla p_{0}=0$,

$v_{0}=0$ on $\mathrm{r}=1$,

および

$\nabla \cdot v_{1}=0$,

$\Delta v_{1}-\nabla p_{1}=\left(v_{0} \cdot \nabla\right) v_{0}$

$\mathrm{v}_{1}=0$ on $\mathrm{r}=1$

が求まる。このオーダーまでは、Vasseur and $\operatorname{Cox}^{1}{ }^{1}$ が示し ているように回転の影響は現れない。

下記の無次元外部变数 $\tilde{\boldsymbol{r}}=(\widetilde{x}, \widetilde{y}, \widetilde{z})$ を導入する。 $\widetilde{\boldsymbol{r}}=\varepsilon \boldsymbol{r}$.

外部展開

$\boldsymbol{v}=\boldsymbol{e}_{z}+\varepsilon \widetilde{v}_{1}+O\left(\varepsilon^{2}\right)$,

$p=\varepsilon^{2} \widetilde{p}_{1}+O\left(\varepsilon^{3}\right)$

を基礎方程式に代入すると、外部基礎方程式

$\widetilde{\nabla} \cdot \widetilde{v}_{1}=0$

$\left(\widetilde{\Delta}-R_{L} \frac{\partial}{\partial z}\right) \widetilde{v}_{1}=\widetilde{\nabla} \widetilde{p}_{1}$

$\tilde{v}_{1} \rightarrow 0$ as $\tilde{r} \rightarrow \infty$

$\widetilde{\boldsymbol{v}}_{1}=0$ on the wall

が求められる。

内部解と外部解は、それらの中間領域で等しくなければなら ないとして、それぞれに含まれる未定定数を定めれば、速度 $v$ で軸方向に進行する単一球に加わる力が求められる。多粒 子が沈降する場合には、これに他の粒子の 2 次誘導流による 力、および他の粒子が引き起こした直接の 1 次誘導流による 相互作用が加わる。

\section{3. 結果}

初め中心軸から反対方向にそれぞれ半径の 0.3 倍離れ、中 心軸とそれぞれを結ぶ直線とが 45 度で交わる位㯰にある 2 粒子が、鉛直円管内を沈降するときの軌跡を示したものが 
Fig. 1〜 5である。鉛直、水平方向のスケールは、管径で無次 元化している。Fig.1,2に示すように、R R が6.73までは、規 則的なジグザグ運動をしていた 2 粒子が、Fig.3、4 に示すよ うに、 $\mathrm{R}_{\mathrm{L}}$ がこの值を超えると軸対称性が破れ、2 粒子が円管 の一方に偏った運動を始める。

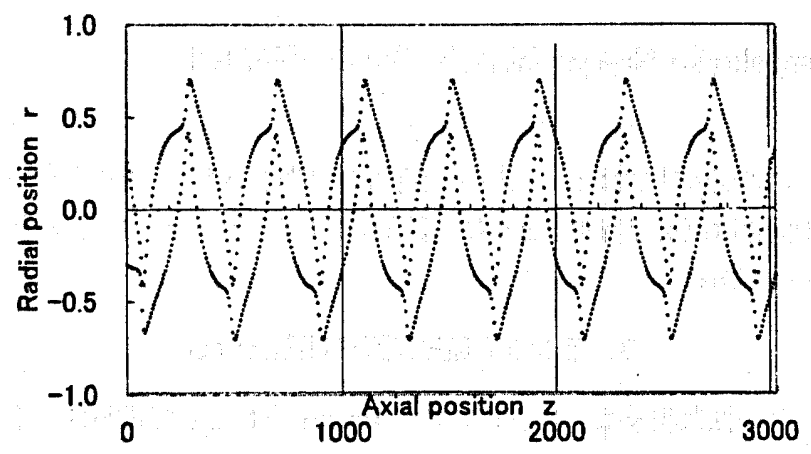

Fig. 1 Positions of two settling spheres $(R L=5)$

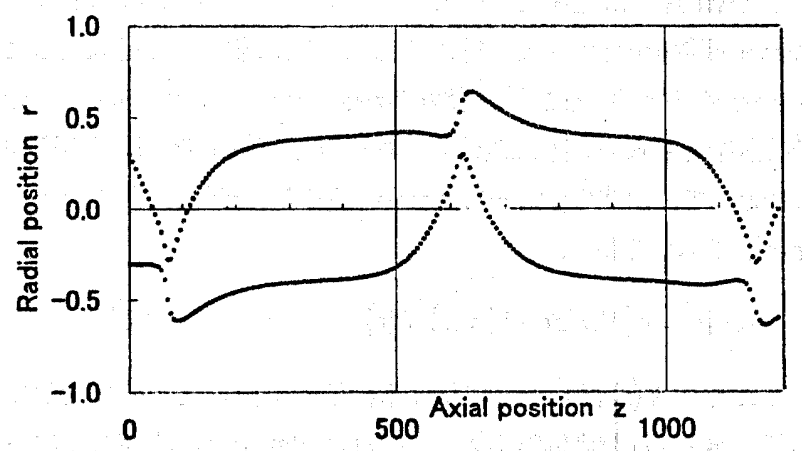

Fig. 2 Positions of two settling spheres $(R L=6.73)$

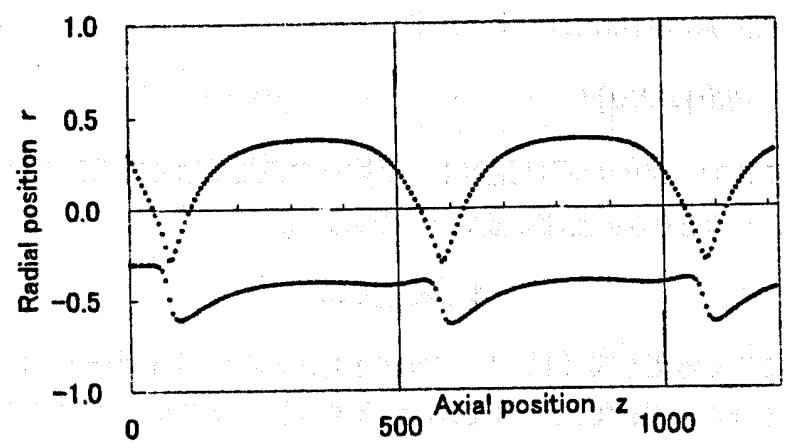

Fig. 3 Positions of two settling spheres $(R L=6.74)$

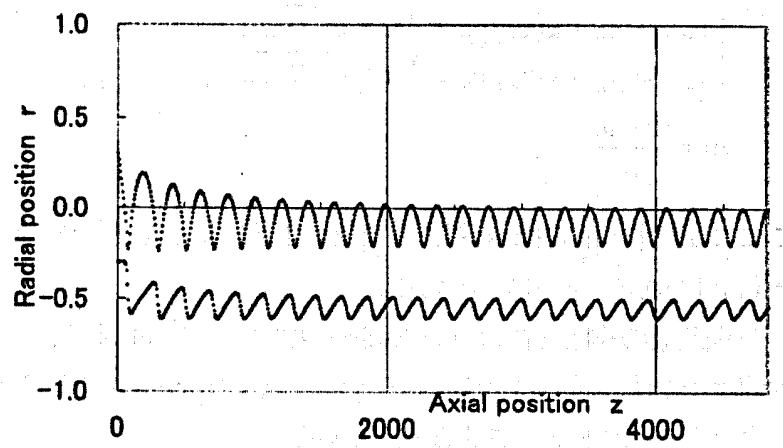

Fig. 4 Positions of two settling spheres $(R L=8)$

RLがさらに大きくなると、Fig.5のように特徵的な振動を 伴って沈降していた 2 粒子が、ある平衡位置に移動すること がわかる。Fig.6に 2 粒子の平衡位直を示す。
管径を基にしたレイノルズ数がさらに大きくなると、2 粒 子はより早く平衡位置に移動し、そのときの鉛直方向粒子間 距離は増加し、管軸との距離は減少する。

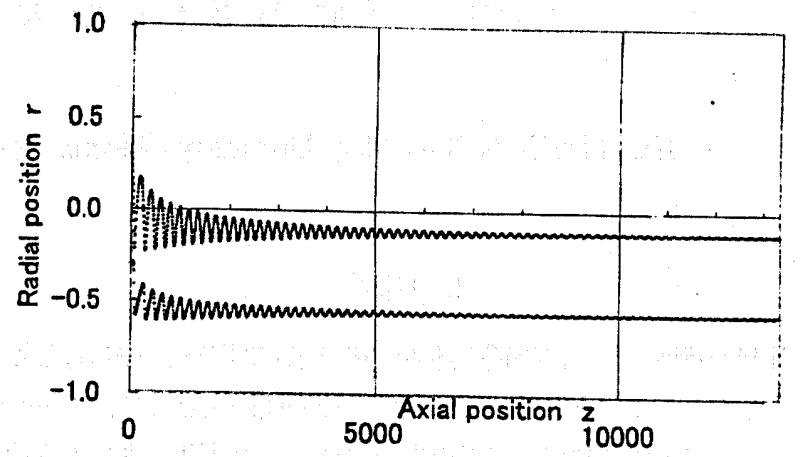

Fig. 5 Positions of two settling spheres $(R L=8.3)$

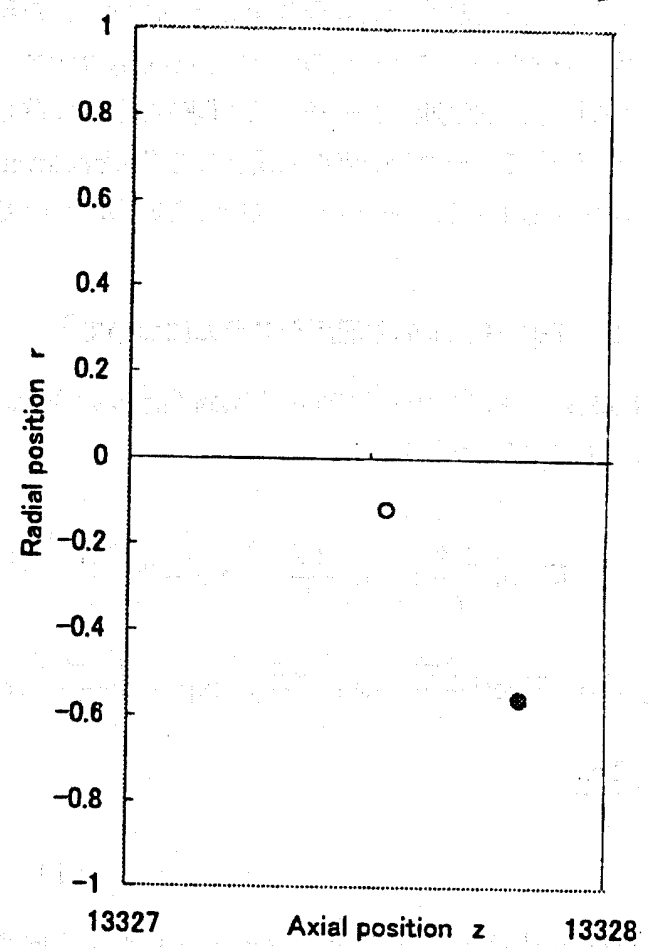

Fig. 6 Equillibrium positions of two settling spheres $(R L=8.3)$

\section{4. 結言}

円管内を沈降する 2 微小球の運動を解析により調べた。管 径を基にしたレイノルズ数が臨界值を超えると、粒子の軌跡 は軸対称でなくなり、振動しながら特定の平衡位置に向かっ て移動することが示された。管径を基にしたレイノルズ数が さらに大きくなると、2 粒子はより早く平衡位置に移動し、 そのときの鉛直方向粒子問距雄は増加し、管軸との距離は減 少した。

\section{参考文献}

1)P. Vasseur \& R. G. Cox: J. Fluid Mech. 80(1977) 561. 2) M. Shinohara: J. Phys. Soc. Japan 61 (1992) 2178. 3) M. Shinohara: J. Phys. Soc. Japan 61 (1992) 4418. 4) M. Shinohara: J. Phys. Soc. Japan 65 (1996) 3858. 